\title{
Permasalahan Pelanggaran Dan Langkah Hukum Hak Cipta Atas Musik Dan Lagu Yang Dituangkan Dalam Bentuk VCD Dan DVD
}

\author{
Budi Agus Riswandi \\ Fakultas Hukum Universitas Islam Indonesia \\ Jl. Tamansiswa No. 158 Yogyakarta \\ budi@fh.uii.ac.id
}

\begin{abstract}
The practice of trading music and songs which is set in the CD's and DVD's and also violate the copyrights on the Mataram Street Yogyakarta is mostly done. This of course invites problems in the context of copyright infringement and also a legal action to minimize it. Along the way, there has done a research related to it by using the method of empirical legal research. And the result are: there are a number of problems for copyright violations both in civil and criminal. Solution is giving the socialization about copyrights law and law enforcement.
\end{abstract}

Key words : Copyright, problem, settlement

\begin{abstract}
Abstrak
Praktek perdagangan musik dan lagu yang melanggar hak cipta dituangkan dalam bentuk VCD dan DVD di lingkungan jalan Mataran Yogyakarta marak dilakukan. Hal ini tentunya mengundang permasalahan dalam konteks pelanggaran hak cipta dan membutuhkan langkah-langkah hukum untuk meminimalisir hal tersebut. Sejalan dengan itu, telah dilakukan penelitian yang berhubungan dengan hal tersebut dengan menggunakan metode penelitian hukum empirik. Hasilnya, terdapat sejumlah permasalahan atas pelanggaran hak cipta baik secara perdata dan pidana. Langkah penyelesaian yang dilaksanakan berupa sosialisasi dan penegakan hukum.
\end{abstract}

Kata kunci : Hak Cipta, permasalahan, penyelesaian 


\section{Pendahuluan}

Pemberlakuan UU No. 19 Tahun 2002 tentang Hak Cipta pada 29 Juli 2003 diyakini banyak pihak mampu memberantas praktek pembajakan hak cipta selama ini di Indonesia. Keyakinan ini didasarkan pada beberapa alasan, di antaranya adanya penyempurnaan terhadap materi UU Hak Cipta sendiri.

Beberapa penyempurnaan dalam UU Hak Cipta meliputi; 1). Database merupakan salah satu ciptaan yang dilindungi; 2). Penggunaan alat apa pun baik melalui kabel maupun tanpa kabel termasuk internet, untuk pemutaran produkproduk cakram optik (optical disk) melalui media audio, media audiovisual, dan/ atau sarana telekomunikasi; 3). Penyelesaian sengketa oleh pengadilan niga arbitrase atau alternative penyelesaian sengketa; 4) penetapan sementara pengadilan untuk mencegah kerugian lebih besar bagi pemegang hak; 5). Batas waktu proses perkara perdata di bidang hak cipta dan hak terkait baik di Pengadilan Niaga maupun di Mahkamah Agung; 6). Pencantuman hak informasi manajemen elektronik dan sarana kontrol teknologi; 7). Pencantuman mekanisme pengawasan dan perlindungan terhadap produk-produk yang menggunakan sarana produksi berteknologi tinggi; 8). Ancaman pidana atas pelanggaran hak terkait; 9). Ancaman pidana dan denda minimal; 10). Ancaman pidana terhadap perbanyakan penggunaan program computer untuk kepentingan komersial secara tidak sah dan melawan hokum.

Melalui penyempurnaan ini, diharapkan maksimalisasi terhadap upaya perlindungan hak cipta dapat diwujudkan. Namun demikian, harus diketahui bahwa upaya memberikan perlindungan hukum terhadap pemegang hak cipta tidak saja didasarkan pada instrumen hukum secara normatif, namun sangat bergantung pula penegakan hukum hak cipta (copyrights law enforcement).

Apabila melihat pada realitasnya Indonesia ternyata masih menduduki posisi yang cukup tinggi dalam pelanggaran hak cipta. Hal ini terbukti dari data yang ada bahwa pada pada awal tahun 2004 Indonesia menurut data IDC, yaitu perusahaan konsultan dan intelejen pasar global dengan 700 analis di sekitar 50 negara - tingkat pembajakan hak cipta sampai $89 \%$, nomor tiga terbesar di dunia setelah Vietnam (95\%) dan Cina (92\%).

Fenomena ini semakin nyata tatkala mencermati apa yang terjadi di wilayah Yogyakarta, khususnya yang terjadi pada para pedagang kaki lima di lingkungan jalan Mataram. Di sana, terlihat banyak sekali para pedagang kaki lima yang 
memperjual belikan barang-barang bajakan, terutama musik dan lagu dalam bentuk VCD/DVD bajakan.

Fenomena ini sangat jelas bahwa praktek pelanggaran hak cipta di Indonesia boleh dikatakan masih marak. Maraknya, pelanggaran hak cipta tidak semata-mata dikarenakan persoalan ketidaktahuan terhadap ketentuan perundang-undangan dalam bidang hak cipta, tetapi hal itu disebabkan faktor-faktor non hukum yang ikut mempengaruhi atas maraknya pelanggaran hak cipta.

Di lain pihak, maraknya pelanggaran hak cipta disebabkan kurang optimalnya langkah-langkah hukum yang dilakukan oleh pemerintah dalam membangun kesadaran hukum hak cipta. Sebagaimana diketahui, penyadaran hukum dapat dilakukan baik melalui kegiatan sosialisasi dan penegakan hukum. Disinyalir sosialisasi yang dilaksanakan terhadap masyrakat terkait dengan hak cipta belum dilakukan dengan menggunakan model pendekatan yang efektif.

Sejalan dengan itu, penegakan hukum hak cipta yang diterapkan pun terkesan seporadis dan tidak menyentuh pada akar permasalahannya. Alhasil, kesadaran untuk menghargai ciptaan orang lain, salah satunya dalam hal musik dan lagu yang dituangkan dalam bentuk VCD/DVD pun tidak tampak. Praktek yang ada masyarakat semakin berani untuk melakukan pelanggaran hukum atas hak orang lain (baca: hak cipta).

\section{Rumusan Masalah}

Setelah menguraikan latar belakang masalah, maka dapat dirumuskan dua permasalahan pokok, yakni:

1. Bagaimanakah problematika hukum pelanggaran hak cipta atas musik dan lagu yang dituangkan dalam bentuk VCD/DVD di lingkungan Jalan Mataram Yogyakarta?

2. Langkah-langkah hukum apakah yang dilakukan dalam mengurangi pelanggaran hukum hak cipta atas musik dan lagu yang dituangkan dalam bentuk VCD/DVD di lingkungan Jalan Mataram Yogyakarta? 


\section{Tujuan Penelitian}

Fokus penelitian akan diarahkan pada dua tujuan utama, yakni:

1. Untuk memahami problematika hukum pelanggaran hak cipta atas musik dan lagu yang dituangkan dalam bentuk VCD/DVD di lingkungan Jalan Mataram Yogyakarta.

2. Untuk mengetahui dan mencari langkah-langkah hukum apakah yang dilakukan dalam upaya mengurangi pelanggaran hukum hak cipta atas musik dan lagu yang dituangkan dalam bentuk VCD/DVD di lingkungan Jalan Mataram Yogyakarta.

\section{Metode Penelitian}

Penelitian ini merupakan tipe penelitian hukum sosiologis. Artinya, penelitian ini menitikberatkan pada kondisi empirik atas problematika pelanggaran hukum hak cipta dan langkah hukum yang ditempuh oleh pemerintah untuk mengurangi tindakan pelanggaran hak cipta atas musik dan lagu yang dituangkan dalam bentuk VCD/DVD di Jalan Mataram Yogyakarta. Oleh karenanya, realitas-realitas di lapangan akan menjadi dasar pijakan dalam menjelaskan duduk permasalahan tersebut, selain mengacu juga kepada norma-norma serta aturan yang berlaku.

Sumber data yang akan digunakan mencakup pada dua macam sumber data, yakni sumber data primer, di mana data-data yang ditemukan bersumberkan dari lapangan langsung, dan sumber data sekunder yakni data-data yang ditemukan bersumber dari kaji atas berbagai kepustakaan.

Untuk memperoleh data tersebut dilakukan teknik pengumpulan data berupa: Pertama, studi kepustakaan, yakni mengkaji berbagai macam literatur yang berkaitan dengan objek yang diteliti. Kedua, wawancara, yakni melakukan proses tanya jawab dengan ahli-ahli di bidang hak cipta, dan; Ketiga, kuesioner, yakni menyebarkan daftar pertanyaan yang selanjutnya akan diisi oleh para pedagang kaki lima di lingkungan Jalan Mataram Yogyakarta. 


\section{Tinjauan Pustaka}

\section{Pengertian dan Ruang Lingkup Hak Cipta}

Perkembangan ilmu pengetahuan dan teknologi telah melahirkan manusia lebih kreatif dan inovatif. Kreatifitas ini di antaranya mencakup pada bidang seni, sastra dan ilmu pengetahuan. Dengan kemampuan manusia melahirkan kreatifitas, kini muncul upaya-upaya untuk memberikan perlindungan dan penghargaan atas keberhasilan dalam melahirkan kreatifitas tersebut. Bentuk dari perlindungan dan penghargaan ini saat ini dikenal dengan istilah hak kekayaan intelektual. Salah satu bagian dari hak kekayaan intelektual yang melingkupi pada bidang seni, sastra dan ilmu pengetahuan dikenal dengan istilah hak cipta.

Dalam sejarah perkembangan istilah hak cipta (bahasa Indonesia yang lazim dipakai sekarang) pada awal mulanya istilah yang dikenal adalah hak pengarang sesuai dengan terjemahan harfiah bahasa Belanda Autersrecht. Baru pada Kongres Kebudayaan Indonesia ke-2 Oktober 1951 di Bandung, penggunaan istilah hak pengarang dipersoalkan karena dipandang menyempitkan pengertian hak cipta. Jika istilah yang dipakai adalah hak pengarang, seolah-olah yang diatur hak cipta hanyalah hak-hak dari pengarang saja dan hanya bersangkut paut dengan karang mengarang saja, sedangkan cakupan hak cipta jauh lebih luas dari hak-hak pengarang. Karena itu, kongres memutuskan untuk mengganti istilah yang diperkenalkan dengan istilah hak cipta. ${ }^{1}$

Suatu kreasi intelektual dalam bidang seni, sastra dan ilmu pengetahuan dapat melahirkan hak cipta. Hak Cipta adalah hak eksklusif bagi pencipta atau penerima hak untuk mengumumkan atau memperbanyak ciptaan atau memberikan izin untuk itu dengan tidak mengurangi pembatasan-pembatasan menurut peraturan perundang-undangan yang berlaku.

L.J. Taylor menyatakan hak cipta melindungi suatu ekspresi dari sebuah ide, sedangkan ide yang belum diwujudkan belum dilindungi. Dari pengertian ini sangat jelas bahwa hak cipta diberikan hanya pada karya-karya yang merupakan penuangan ide secara nyata, bukan sekedar gagasan dan ide semata.

Pengertian hak cipta yang diuraikan di atas selain memberikan pemahaman tentang hak cipta dalam pengertian itu menunjukkan karakteristik dari hak cipta.

${ }^{1}$ Edy Damian, Hukum Hak Cipta UU No. 19 Tahun 2002, Bandung, Alumni, 2004, hlm. 112. 
Karakteristik hak cipta mencakup pada: Pertama, pemegang hak cipta terdiri dari pencipta atau penerima hak; Kedua, hak eksklusif untuk mengumumkan atau memperbanyak; Ketiga; dapat diberikan hak eksklusif tersebut kepada pihak lain dengan memberi izin; Keempat, hak cipta timbul secara otomatis; hak cipta mencakup pada bidang seni, sastra dan ilmu pengetahuan.

Hak cipta memiliki dua macam hak, yakni hak moral dan hak ekonomi. Hak moral adalah hak yang melekat pada diri pencipta. Hak moral diatur di dalam ketentuan Pasal 24 ayat (1), (2), (3), dan (4) UU Hak Cipta. ${ }^{2}$

Dari ketentuan ini dapat ditetapkan bahwa moral meliputi pada: Pertama, nama pencipta harus dicantumkan dalam ciptaannya; Kedua, ciptaan tidak boleh diubah kecuali atas persetujuan pencipta atau ahli waris; Ketiga, nama pencipta atau nama samaran pencipta tidak boleh dilakukan perubahan; Keempat, judul dan anak judul ciptaan tidak boleh dilakukan perubahan.

Muhammad Djumhana mengemukakan bahwa hak moral adalah hak-hak yang melindungi kepentingan pribadi si pencipta. Konsep hak moral ini berasal dari sistem hukum kontinental, yaitu Perancis. Menurut konsep hukum kontinental hak pengarang (droit d'auteur, author rights) terbagi menjadi hak ekonomi untuk mendapatkan keuntungan yang bernilai ekonomi seperti uang, dan hak moral yang menyangkut perlindungan atas reputasi si pencipta. ${ }^{3}$

Di setiap negara umumnya hak ekonomi di dalam hak cipta terdiri dari: hak reproduksi atau penggandaan, hak adaptasi, hak distribusi, hak penampilan (performance rights), hak penyiaran (brodcasting right), hak program kabel, droit de suite, dan hak pinjam masyarakat (public lending rights). ${ }^{4}$

Lingkup hak cipta meliputi pada bidang seni, sastra dan ilmu pengetahuan. Pasal 12 ayat (1) UU Hak Cipta menentukan jenis-jenis ciptaan yang diberikan hak cipta secara terperinci. Penetapan beberapa jenis ciptaan yang diberikan hak cipta

${ }^{2}$ Selengkapnya bunyi ketentuan Pasal 24 ayat (1), (2), 3) dan (4) UU Hak Cipta adalah:

(1) Pencipta atau ahli warisnya berhak menuntut pemegang hak cipta supaya nama pencipta tetap dicantumkan dalam ciptaannya.

(2) Suatu ciptaan tidak boleh diubah walaupun hak ciptanya telah diserahkan kepada pihak lain, kecuali dengan persetujuan pencipta atau dengan persetujuan ahli warisnya dalam hal pencipta telah meninggal dunia.

(3) Ketentuan sebagaimana dimaksud pada ayat (2) berlaku juga terhadap perubahan judul dan anak judul ciptaan, pencantuman dan perubahan nama atau nama samaran pencipta.

(4) Pencipta tetap berhak mengadakan perubahan pada Ciptaannya sesuai dengan kepatutan dalam masyarakat.

${ }^{3}$ Muhammad Jumhana, Hak Kekayaan Intelektual Teori dan Prakteknya, Bandung, Citra Aditya Bakti, 1997, hlm.

72.

$$
{ }^{4} \text { Ibid. }
$$


ini sebenarnya tidak membatasi atas pemberian hak cipta atas ciptaan lain di luar yang ditetapkan berdasarkan ketentuan Pasal 12 ayat (1) UU Hak Cipta.

\section{Perolehan Hak Cipta}

Untuk memperoleh hak cipta, pemegang hak cipta berdasarkan ketentuan hukum hak cipta bersifat otomatis tatkala ciptaan diwujudkan secara nyata. Hal ini didasarkan pada ketentuan Pasal 2 ayat (1) UU Hak Cipta yang menyatakan:

Hak Cipta merupakan hak eksklusif bagi pencipta atau pemegang hak cipta untuk mengumumkan atau memperbanyak ciptaannya, yang timbul secara otomatis setelah suatu ciptaan dilahirkan tanpa mengurangi pembatasan menurut perturan perundang-undangan yang berlaku.

Dengan konsepsi perolehan hak cipta, maka apapun bentuk ciptaannya sepanjang tidak dikategorikan sebagai ciptaan yang tidak ada hak cipta dan dan diwujudkan secara nyata dalam lingkup bidang seni,sastra dan ilmu pengetahuan dapat memperoleh hak cipta.

Apabila saat ini ada yang berpandangan bahwa hak cipta diperoleh melalui mekanisme pendaftaran sebenarnya merupakan pandangan yang tidak tepat. Pendaftaran ciptaan memang terdapat pengaturannya. Pengaturan tersebut ditemukan dalam ketentuan Pasal 35 ayat (1), (2), (3), dan (4) UU Hak Cipta yang menyatakan:

(1) Direktorat Jenderal menyelenggarakan pendaftaran ciptaan dan dicatat dalam daftar umum ciptaan.

(2) Daftar umum ciptaan tersebut dapat dilihat oleh setiap orang tanpa dikenai biaya.

(3) Setiap orang dapat memperoleh untuk dirinya sendiri suatu petikan dari daftar umum ciptaan tersebut dengan dikenai biaya.

(4) Ketentuan tentang pendaftaran sebagaimana dimaksud pada ayat (1) tidak merupakan kewajiban untuk mendapatkan hak cipta.

Berdasarkan ketentuan ini dapat diketahui, lembaga yang menyelenggarakan pendaftaran adalah Direktorat Jenderal HKI. Ciptaan yang terdaftar akan dimuat dalam Daftar Umum ciptaan yang dapat diakses oleh publik. Di samping dapat akses kepada Daftar Umum ciptaan, khusus untuk petikan daftar umum juga dapat diakses oleh publik tanpa dikenai biaya. Sejalan dengan ketentuan Pasal 35 UU Hak cipta, Pasal 37 sampai Pasal 44 UU Hak Cipta mengatur lebih jelas prosedur pendaftaran ciptaan. 
Adapun inti dari prosedur pendaftaran ciptaan yang dimaksud dimulai dengan pengajuan permohonan ke Direktorat Jenderal HKI. Direktorat Jenderal HKI dilakukan pemeriksaan. Pemeriksaan ini meliputi dua macam, yakni pemeriksaan administratif, di mana yang diperiksa berupa kelengkapan persyaratan - persyaratan administratif dan pemeriksaan substantif, di mana yang diperiksa berupa keorisinalan ciptaan dari pencipta atau pemegang hak cipta atas ciptaan yang dimohonkan.

Apabila dalam pemeriksaan administratif ada kekuranglengkapan, maka akan diberitahukan kepada pemohon. Kemudian, apabila dalam pemeriksaan substantif tidak ada nilai orisinalitasnya dari ciptaan, maka permohonan pendaftaran ciptaan akan ditolak.

Penentuan orisinalitas, dapat dipahami dalam konteks karya tersebut haruslah dihasilkan oleh orang yang mengakui karya tersebut sebagai karangan atau ciptaannya. Karya tersebut tidak boleh dikopi atau direproduksi dari karya lain. Jika si pencipta atau pengarang telah menerapkan tingkat pengetahuan, keahlian dan penilaian yang cukup tinggi dalam proses penciptaan karyanya, hal ini sudah dianggap cukup memenuhi sifat keaslian guna memperoleh perlindungan hak cipta. ${ }^{5}$

Ciptaan yang dihasilkan tersebut akan merupakan ciptaan asli, jika ciptaan tersebut tidak merupakan jiplakan/tiruan dari ciptaan lain dari pencipta telah menggunakan kemampuan pikiran, imajinasi, kecekatan, keterampilan atau keahlian yang dituangkan ke dalam bentuk yang khas dan pribadi. ${ }^{6}$

Untuk pemohon yang tidak dapat menerima penolakan pendaftaran ciptaan dapat mengajukan keberatan ke Pengadilan Niaga. Bagi permohonan pendaftaran ciptaan yang telah memenuhi kelengkapan administratif dan orisinalitas dapat dipastikan permohonan ciptaannya akan didaftar. Setelah dilakukan pendaftaran, maka dimuat di dalam Daftar Umum dan dalam Tambahan Berita Negara.

Permohonan pendaftaran ciptaan tersebut, Direktorat Jenderal HKI akan memberikan keputusan paling lama 9 (sembilan) bulan terhitung sejak tanggal diterimanya permohonan secara lengkap. ${ }^{7}$ Perlu diketahui, pendaftaran ciptaan sebagaimana yang telah diuraikan tadi pada dasarnya bukan merupakan sarana untuk memperoleh hak cipta. Hal ini sejalan dengan Penjelasan ketentuan Pasal 35 ayat (4) UU Hak Cipta.

\footnotetext{
${ }^{5}$ Tim Linsey dkk., Hak. Kekayaan Intelektual Suatu Pengantar, Bandung, Alumni, 2005, hlm. 106.

${ }^{6}$ Ibid.

${ }^{7}$ Rachmadi Usman, Hukum Hak Atas Kekayaan Intlektual Perlindungan dan Dimensi Hukumnya di Indonesia, Bandung, PT. Alumni, 2003, hlm. 139
} 
Dari paparan secara keseluruahan mengenai perolehan hak cipta dapat diketahui, hak cipta diperoleh secara otomatis ketika ciptaan dilahirkan. Pendaftaran ciptaan sebagai sebuah ketentuan di dalam UU Hak Cipta bukanlah sebagai sarana untuk memperoleh hak cipta.

\section{Bentuk Pelanggaran dan Mekansime Penyelesaian Pelanggaran Hak Cipta}

Hak cipta sebagai hak monopoli, di mana di dalamnya terdapat dua macam hak, sangat potensial mengalami pelanggaran. Pelanggaran tersebut dapat mencakup pada pelanggaran hak moral dan hak ekonomi. Pelanggaran hak moral atas ciptaan dapat diwujudkan dengan tidak mencantumkan nama pencipta atau melakukan perubahan atas ciptaan tanpa seizin penciptanya.

Pelanggaran hak ekonomi atas ciptaan dapat diwujudkan dengan melakukan pengumuman dan perbanyakan yang dimaksudkan untuk tujuan komersial.. Pelanggaran hak cipta selain dapat dilihat dari segi isi hak cipta sendiri, dapat juga dilihat dari sisi bentuk pelanggarannya. Pelanggaran hak cipta ini dapat berupa pelanggaran hak cipta yang mengandung unsur keperdataan dan pelanggaran hak cipta yang mengandung unsur pidana.

Pelanggaran hak cipta yang mengandung unsur keperdataan biasanya dibuktikan dengan adanya kerugian dari pihak pencipta atau pemegang hak cipta baik secara materiil maupun imateriil, sedangka pelanggaran hak cipta yang mengandung unsur pidana dibuktikan dengan terpenuhinya unsur-unsur sebagaimana yang tertuang di dalam ketentuan Pasal 72 ayat (1), (2), (3), (4), (5), (6), (7), (8), (9) UU Hak Cipta. Menurut Trisno Raharjo dari ketentuan ini dapat ditentukan jenis pelanggaran hak cipta yang mengandung unsur pidana, yakni:

(1) Tanpa hak mengumumkan atau memperbanyak ciptaan dan hak terkait.

(2) Menyiarkan, memamerkan, mengedarkan atau menjual kepada umum suatu ciptaan atau hak terkait yang berasal dari pelanggaran hak cipta.

(3) Tanpa hak memperbanyak penggunaan untuk kepentingan komersial suatu program komputer.

(4) Larangan pengumuman ciptaan bertentangan dengan kebijaksanaan pemerintah di bidang pertahanan dan keamanan negara, kesusilaan serta ketertiban umum.

(5) Tanpa izin memperbanyak atau mengumumkan potret seseorang atau potret yang memuat dua orang atau lebih.

(6) Tanpa hak mengubah hak cipta, judul, anak judul dan mengubah nama atau nama samaran pencipta serta tidak mencantumkan nama pencipta. 
(7) Tanpa hak meniadakan atau mengubah informasi elektronik tentang informasi menajemen hak pencipta.

(8) Tanpa hak merusak, meniadakan atau membuat tidak berfungsi saran kontrol teknologi pengaman hak pencipta.

(9) Tanpa izin tidak memenuhi persyaratan produksi yang ditetapkan guna menghasilkan ciptaan yang menggunakan sarana produksi berteknologi tinggi khususnya di bidang cakram optik.

Sementara itu ketentuan Pasal 72 ayat (1), (2), (3) dan Pasal 73 ayat (1) UU Hak Cipta memuat unsur-unsur pelanggaran sebagai berikut: 1). Barangsiapa; 2). Dengan sengaja; 3). Tanpa hak; 4). Mengumumkan, memperbanyak, menyiarkan, memamerkan, mengedarkan atau menjual; 5). Hak cipta dan hak terkait. ${ }^{8}$ Uraian dari setiap unsur tersebut dapat dikemukakan sebagai berikut: ${ }^{9}$

Pertama, unsur barangsiapa. Ini menandakan yang menjadi subjek delik adalah: "siapapun". Kalau menurut KUH Pidana yang berlaku sekarang, hanya manusia yang menjadi subjek delik, sedangkan badan hukum tidak menjadi subjek delik. Tetapi, dalam undang-undang khusus seperti Undang-Undang Tidak Pidana Ekonomi, badan hukum atau korporasi juga menjadi subjek delik. Dalam hal ini barangsiapa termasuk pula "badan hukum" atau "korporasi". Dalam UU Hak Cipta, "barangsiapa" bisa ditunjuk antara lain, kepada pelaku dan produser rekaman suara. Pelaku adalah aktor, penyanyi, pemusik, penari, atau mereka yang menampilkan, memperagakan, mempertunjukkan, menyanyikan, menyampaikan, mendeklamasikan atau memainkan suatu karya musik, drama, tari, sastra, foklor, atau karya seni lainnya. Produser rekamana suara adalah orang atau badan hukum yang pertama kali merekam dan memiliki tanggung jawab untuk melaksanakan perekaman suara atau perekaman bunyi, baik perekaman dari suatu pertunjukan maupun perekaman suara atau perekaman bunyi lainnya.

Kedua, unsur dengan sengaja. Kebanyakan tindak pidana mempunyai unsur kesengajan atau opzet bukan unsur culpa (kelalaian). Ini adalah layak, oleh karena biasanya yang pantas mendapat hukuman pidana itu ialah orang yang melakukan sesuatu dengan sengaja. Kesengajan ini dapat berupa kesengajaan yang bersifat tujuan (oogmerk), kesengajaan secara keinsafan kepastian (Opzet bij zekerheidsbewustzijn), dan kesengajaan secara keinsfan kemungkinan (Opzet bij mogelijkheidsbewustzjin).

\footnotetext{
${ }^{8}$ Hendra Tanu Wijaya, Hak Cipta Musik atau Lagu, Jakarta, UI Press, 2003, hlm.98.

${ }^{9}$ Ibid.
} 
Ketiga, unsur tanpa hak. Mengenai arti tanpa hak dari sifat melanggar hukum, dapat dikatakan bahwa mungkin seseorang tidak mempunyai hak untuk melakukan suatu perbuatan yang sama sekali tidak dilarang oleh suatu peraturan hukum. Menurut ketentuan Pasal 1 angka 4 UU Hak Cipta, pemegang hak cipta adalah pencipta sebagai pemilik hak cipta atau pihak yang menerima hak tersebut dari pencipta. Pemilik hak cipta dapat mengalihkan atau menguasakan sebagai atau seluruh haknya kepada orang/badan hukum baik melalui perjanjian, surat kuasa maupun dihibahkan atau diwariskan. Tanpa pengalihan atau kuasa tersebut, maka tindakan itu merupakan "tanpa hak."

Keempat, unsur perbuatan dapat dikualifikasikan dalam bentuk mengumumkan. Menurut ketentuan Pasal 1 ayat (5) UU Hak Cipta, pengumuman adalah pembacaan, penyiaran, pameran, penjualan, pengedaran atau penyebaran suatu ciptaan dengan menggunakan alat apa pun, termasuk media internet, atau melakukan dengan cara apa pun, sehingga suatu ciptaan dapat dibaca, didengar, atau dilihat orang lain; dan unsur memmperbanyak (perbanyakan), menurut ketentuan Pasal 1 ayat (6) UU Hak Cipta, adalah penambahan jumlah suatu ciptaan, baik secara keseluruhan maupun sebagian yang sangat substansial dengan menggunakan bahan-bahan yang sama ataupun tidak sama, termasuk mengalihwujudkan secara permanen atau temporer.

Kelima, hak cipta. Menurut ketentuan Pasal 1 ayat (1) UU Hak Cipta adalah hak eksklusif bagi pencipta atau penerima hak untuk mengumumkan atau memperbanyak ciptaannya atau memberikan izin untuk itu, dengan tidak mengurangi pembatasanpembatasan menurut peraturan perundang-undangan yang berlaku. Hak terkait menurut ketentuan Pasal 1 angkat 9 UU Hak Cipta adalah hak yang berkaitan dengan hak cipta, yaitu hak eksklusif bagi pelaku untuk memperbanyak atau menyiarkan pertunjukannya, bagi produsen rekaman suara untuk memperbanyak atau menyewakan karya rekaman suara atau rekaman bunyinya dan bagi lembaga penyiaran untuk membuat, memperbanyak atau meniarkan karya siarannya.

Pelanggaran hak cipta dalam konteks musik dan lagu dikenal juga dengan pembajakan. Menurut Hendra Tanu Atmadja, pembajakan dapat dibagi ke dalam tiga kategori, yakni: ${ }^{10}$

Pertama, pembajakan sederhana, di mana suatu rekaman asli dibuat duplikatnya untuk diperdagangan tanpa seizin produser atau pemegang hak yang sah. Rekaman 
hasil bajakan dikemas sedemikian rupa, sehingga berbeda dengan kemasan rekaman aslinya.

Kedua, rekaman yang dibuat duplikatnya, kemudian dikemas sedapat mungkin mirip dengan aslinya, tanpa izin dari pemegang hak ciptanya. Logo dan merek ditiru untuk mengelabui masyarakat, agar mereka percaya bahwa yang dibeli itu adalah hasil produksi yang asli.

Ketiga, penggandaan perekaman pertunjukan artis-artis tertentu tanpa izin dari artisnya tersebut atau dari komposer atau tanpa persetujuan dari produsen rekaman yang mengikat artis bersangkutan dalam suatu perjanjian kontrak.

Pelanggaran hak cipta dengan pembajakan pada musik dan lagu ini dapat merugikan pemegang hak dan masyarakat secara luas. Sebagai perbandingan bahwa pelanggaran hak cipta dapat merugikan secara ekonomi dilihat pada beberapa kasus yang terjadi di Eropa. Pada tahun 1993 menunjukkan bahwa cukup banyak kerugian yang dialami para kreator karena kreasi-kreasinya di bidang musik di bajak oleh pihak lain. Sebagai contoh, di Jerman, Italia dan Polandia jumlah kerugian yang dialami para kreator masing-masing mencapai lebih dari U\$. 100.000.000,00 (seratus juta dolar) atau lebih dari Rp. 200.000.000.000,00 (dua ratus milyar rupiah). Begitu pula kerugian yang dialami oleh para penerbit di Inggris atas pembajakan penerbitan yang terjadi di manca negara telah mencapai lebih dari 200.000.000,00 (dua ratus juta poundsterling) atau lebih dari Rp. 600.000.000.000,00 (enam ratus milyar rupiah). Dalam data ini, kerugian yang dialaminya di Indonesia mencapai 15.000.000,00 (lima belas juta poundsterling) pada tahun 1993, sedangkan penyalahgunaan program komputer pada tahun 1993 tidak hanya terjadi di negara-negara berkembang seperti Thailand yang mencapai 99\% (sembilan puluh persen) atau senilai U\$181.000.000,00 (seratus delapan puluh satu juta dolar), tetapi juga di negara-negara industri maju seperti Jepang yang mencapai 92\% (sembilan puluh dua persen) atau senilai U\$3.000.000.000,00 (tiga milyar dolar), Perancis, Jerman dan Italia penyalahgunaannya mencapai lebih dari 50\% (lima puhlu persen). ${ }^{11}$

Melihat pada bentuk pelanggaran di atas dibutuhkan upaya penyelesaian sengketa pelanggaran hak cipta. Sebelum berlakunya Persetujuan TRIPs tidak ada satupun perjanjian internasional, termasuk Konvensi Bern yang mengatur secara terinci tentang prosedur penegakan hukum bagi perlindungan hak cipta. Menurut Pasal 41 ayat (1) TRIPs adalah menjadi kewajiban negara peserta menjamin prosedur

\footnotetext{
${ }^{11}$ Insan Budi Maulana, Pelangi HKI dan Anti Monopoli, Yogyakarta, FH UII, 2000, hlm. 158.
} 
penegakan hukum yang dapat diterapkan dalam hukum negara peserta perjanjian seperti dimungkinkannya melakukan tindakan efektif terhadap setiap perbuatan melanggar HKI yang dilindungi perjanjian ini. ${ }^{12}$

Mekanisme menyelesaikan pelanggaran hak cipta yang mengandung unsur keperdataan dapat diawali dengan mengajukan gugatan ke Pengadilan Niaga atau dapat diselesaikan dengan menggunakan mekanisme alternatif penyelesaian sengketa dan arbitrase sebagaimana yang diatur dalam UU No. 30 Tahun 1999 tentang Alternatif Penyelesaian Sengketa dan Arbitrase.

Apabila penyelesaian melalui gugatan ke Pengadilan Niaga masih dianggap belum memberikan rasa keadilan kepada pihak-pihak, maka dapat dilakukan upaya hukum berupa kasasi ke Mahkamah Agung dan pada akhirnya dapat melakukan upaya hukum peninjauan kembali kepada Mahkamah Agung.

Dalam konteks penyelesaian pelanggaran hak cipta ini dikenal ada ketentuan tentang penetapan sementara (injunctions). Adanya ketentuan penetapan sementara sebagai kewenangan akim Pengadilan Niaga ini dimaksudkan untuk mencegah kerugian yang lebih besar pada pihak yang haknya dilanggar. Untuk keperluan ini atas permohonan pemegang hak cipta, hakim Pengadilan Niaga diberi kewenangan untuk menerbitkan penetapan sementara dengan segera dan efektif guna mencegah berlanjutnya pelanggaran dan masuknya barang yang diduga melanggar hak cipta dan hak terkait ke jalur perdagangan termasuk tindakan importasi. ${ }^{13}$

Penetapan sementara sebagai upaya hukum yang dapat dikeluarkan oleh Pengadilan Niaga dengan segera dan efektif menimbulkan beberapa persoalan yang perlu difikirkan pemecahannya. Upaya hukum penetapan sementara dalam hukum Indonesia merupakan suatu sistem hukum baru. Ada kemiripan dengan putusan sela yang dikenal dalam sistem hukum Indonesia. Namun, terdapat perbedaan hakiki antara putusan sela dan penetapan sementara yang telah lama dikenal dan sering dipakai dalam pengadilan negara-negara dengan sistem hukum anglo saxon. Penetapan sementara adalah suatu keputusan pengadilan niaga yang mendahului pemeriksaan suatu perkara, yang berarti sebelum pokok perkara diperiksa oleh hakim pengadilan niaga. Sedangkan putusan sela berdasarkan Pasal 108 HIR dapat diajukan permohonannya oleh pihak yang berperkara pada saat perkara sedang berproses di pengadilan. ${ }^{14}$

\footnotetext{
${ }^{12}$ Edy Damian, Op.,Cit., hlm. 261.

${ }^{13}$ Ibid.

${ }^{14}$ Ibid.
} 
Hak untuk mengajukan gugatan perdata sebagaimana diuraikan di atas tidak mengurangi hak negara untuk melakukan tuntutan pidana terhadap pelanggaran hak cipta. Untuk mekanisme penyelesaian pelanggaran hak cipta yang mengandung unsur pidana dapat diselesaikan dengan peran aktif dari aparat penegak hukum. Proses penyelesaian pelanggaran hak cipta dalam konteks ini dapat dilakukan melalui proses penyidikan, penuntutan dan pemeriksaan di Pengadilan Negeri.

Apabila putusan di Pengadilan Negeri dianggap belum dapat memberikan rasa keadilan, maka dapat dilakukan upaya hukum berupa banding ke Pengadilan Tinggi dan kasasi serta peninjauan kembali ke Mahkamah Agung.

Perlu diketahui, delik pidana yang dianut ileh UU Hak Cipta berupa delik biasa. Di mana pihak penyidik dapat secara pro aktif melakukan tindakan hukum kepada pihak pelanggar tanpa harus menunggu adanya pengaduan dari pihak yang dirugikan.

\section{Hasil dan Pembahasan}

\section{Permasalahan Pelanggaran Hak Cipta atas Musik dan Lagu yang Dituangkan dalam Bentuk VCD/DVD di Jalan Mataram Yogyakarta}

Lokasi perdagangan VCD/DVD/CD bajakan yang sangat populer di Daerah Istimewa Yogyakarta berada di sepanjang Jalan Mataram. Daerah tersebut merupakan kawasan yang sangat strategis, karena terletak di pusat kota Yogyakarta, yakni berada di sebelah Timur Jalan Malioboro dan sebelah barat sungai (kali) Code.

Para pedagang VCD/DVD/CD bajakan ini latar belakang pendidikannya ratarata berpendidikan sekolah dasar hingga sekolah menengah umum. Dari segi latar belakang sosial ekonominya mereka dapat dikategorikan sebagai masyarakat bawah. Pedagang VCD/DVD/CD bajakan sendiri sebagian besar berasal dari lingkungan jalan mataram dan selebihnya berasal dari luar jalan Mataram. ${ }^{15}$

Para pedagang VCD/DVD/CD bajakan rata-rata telah melakukan perdagangan di Jalan Mataram rata-rata lebih dari 3 (tiga) tahun. Lama waktu perdagangan VCD/ DVD/CD bajakan di lingkungan Jalan Mataram ini biasanya dimulai dari jam 07.30 berakhir jam 22.00. Waktu biasanya dibagi menjadi dua sampai tiga shift. Sementara itu, yang menjaga kios sebagian besar mereka bukan dari pemilik kios tersebut. ${ }^{16}$

\footnotetext{
${ }^{15}$ Hasil wawancara dengan para pedagang VCD/DVD bajakan di Jalam Mataram hari Sabtu tanggal 14 Juli 2007 yang dilaksanakan oleh Saudara Bayu Aji Pramono dan Reza Agung Dwi Kurniawan.

${ }^{16}$ Data ini diperoleh dengan metode wawancara seperti halnya dengan data yang ada sebelumnya.
} 
VCD dan DVD bajakan yang dipedagangkan itu meliputi VCD yang berisi musik dan lagu dan DVD yang berisi film, sedangkan VCD maupun DVD kosong mereka tidak memperdagangkan. Transaksi perdagangan VCD dijual sebesar rata-rata sebesar Rp. 3.000,-/keping, DVD dijual sebesar Rp. 7.000,-/keping, sedangkan CD dijual sebesar Rp. 4.000,-/ keping.

Adapun VCD, DVD dan CD yang bermuatan musik dan lagu serta film tidak saja musik, lagu dan film yang berasal dari dalam negeri, tetapi ada juga yang berasal dari luar negeri. Contoh VCD musik dan lagu yang berasal dari luar negeri TATAYOUNG yang berasal dari Thailand, sedangkan untuk DVD seperti Film yang berjudul The Pirate of Carribien 3. Untuk VCD musik dan lagu yang berasal dari dalam negeri seperti musik dan lagu milik Peterpan, Ada Band dan sebagainya, untuk filmnya yang dimuat dalam bentuk DVD seperti, film Kuntilanak, Pocong dan lain sebagainya, sedangkan musik dan lagu yang dibajak dalam bentuk CD seperti musik dan lagu, Slank, Gigi, Melly Goeslow, Dewa dan banyak lagi yang lainnya.

Biasanya perdagangan VCD/DVD/CD bajakan yang paling laku didominasi oleh VCD/DVD/CD bajakan yang isinya merupakan hal terbaru. Pedagang VCD, DVD dan CD bajakan setiap kiosnya memperdagangkan kurang lebih 500 keping VCD, DVD dan CD, sementara itu di Jalan Mataram ada kira-kira 30 (tiga puluh kios) yang melakukan perdagangan VCD/DVD/CD bajakan. Dari tiga puluh kios tersebut ada yang sifatnya kios permanen dan temporer. Dari tiga puluh kios ini sebenarnya ada satu kios yang bernama Playerindo yang selain melakukan perdagangan kepada konsumen langsung juga mensuplay ke beberapa kios lainnya.

Perlu diketahui bahwa disekitar pedagang VCD/DVD/CD bajakan ini terdapat juga kios permanen yang memperdagangkan VCD/DVD/CD legal. Kios permanen ini adalah Popeye.

Dalam transaksi perdagangan VCD/DVD/CD bajakan ini diketemukan ada banyak pihak yang terlibat. Pihak-pihak disini tidak hanya antara pedagang dengan pembeli/konsumen, tetapi ada pihak-pihak lainnya, yakni; supplier, preman, polisi dan petugas retribusi dan tukang parkir.

Dari praktek perdagangan VCD/DVD bajakan, maka sangat jelas bahwa praktek perdagangan VCD/DVD bajakan merupakan suatu tindakan pelanggaran hukum hak cipta. Pelanggaran hukum hak cipta ini dapat menimbulkan kerugian yang sangat luas. Pelanggaran hak cipta bukan hanya merugikan "economic rights" dari pemilik 
atau pemegang hak, namun dalam skala yang lebih luas juga menimbulkan dampak negatif bagi pemerintah serta masyarakat luas, yang secara totalitas menimbulkan kerugian yang sangat besar. ${ }^{17}$

Menurut Ditjen Bea Cukai kerugian-kerugian tersebut secara jelas lagi dapat dibagi kepada 3 pihak, yakni: ${ }^{18}$

\section{Kerugian konsumen}

Konsumen harus membayar mahal untuk barang palus, berkualitas rendah, mudah rusak dan mengakibatkan kerusakan materi serta membahayakan kesehatan dan keselamatan jiwa.

\section{Kerugian masyarakat usaha, pemegang hak, pencipta}

Turunnya nilai penjualan, kerugian finansial, kerugian moral (moral rights), rusaknya reputasi, menurunnya kreatifitas dan hilangnya insentif untuk melakukan inovasi, terganggunya pengembangan teknologi.

\section{3. kerugian pemerintah, negara dan perekonomian}

Terganggunya perekonomian nasional, hilangnya pendapatan pajak, hilangnya kepercayaan internasional, rusaknya moralitas bangsa, terhambatnya alih tekonologi baru, keengganan PMA untuk invenstasi, terhambatnya akses pasar untuk komoditi ekspor, ancaman terhadap perdagangan internasional.

Dalam hal pelanggaran hukum hak cipta sendiri, bentuk pelanggaran ini ada yang bersifat keperdataan dan ada yang bersifat pidana. Dalam kaitannya dengan sifat keperdataan, dalam praktek perdagangan VCD/DVD bajakan ini pihak pedagang telah melanggar hak ekonomi dari pencipta/pemegang hak cipta. Pelanggaran hak ekonomi tersebut berupa pengumuman. Menurut ketentuan Pasal 1 angka 5 UU Hak Cipta yang menyatakan bahwa pengumuman adalah pembacaan, penyiaran, pameran, penjualan, pengedaran atau penyebaran suatu ciptaan dengan menggunakan alat apapun, termasuk media internet, atau melakukan dengan cara apa pun sehingga suatu ciptaan dapat dibaca, didengar atau dilihat orang lain.

Dari bunyi ketentuan tadi sangat jelas bahwa melakukan penjualan ciptaan yang dilindungi hak cipta merupakan bentuk pengumuman. Hal yang dipraktekkan oleh pedagang VCD/DVD bajakan berupa mengumumkan (baca: menjual) tanpa izin

\footnotetext{
${ }^{17}$ Data Diperoleh dari Ditjen Bea Cukai Tahun 2003.

${ }^{18}$ Data diperoleh dari Ditjen Bea Cukai Tahun 2003.
} 
dari pemegang hak cipta, di mana tindakan ini merupakan pelanggaran hukum hak cipta.

Apabila pelanggaran hukum hak cipta ini dilihat dari sisi keperdataan, maka pemegang hak cipta dapat melakukan upaya-upaya hukum berupa gugatan ke Pengadilan Niaga. Di dalam Pasal 56 ayat (1) UU Hak Cipta menyatakan: “Pemegang hak cipta berhak mengajukan gugatan ganti rugi kepada Pengadilan Niaga atas pelanggaran hak ciptaannya dan meminta penyitaan terhadap benda yang diumumkan atau hasil perbanyakan ciptaan itu."

Selanjutnya di dalam Pasal 56 ayat (3) UU Hak Cipta memberikan upaya pencegahan melalui peran aktif hakim berupa pengeluaran perintah kepada pelanggar untuk menghentikan kegiatan pengumuman dan/atau perbanyakan ciptaan atau barang yang merupakan hasil pelanggaran hak cipta.

Upaya pencegahan selain yang di atur sebagaimana tersebut di atas, dapat dilakukan juga melalui permintaan dari pihak yang merasa dirugikan. Model ini dikenal dengan istilah penetapan sementara pengadilan atau injunction. Biasanya, permintaan seperti ini terjadi tatkala hakim sebelum memeriksa gugatan tersebut.

Ada beberapa tujuan tatkala ada pihak yang merasa dirugikan meminta untuk dilakukan penetapan sementara. Tujuannya adalah: ${ }^{19}$

1. Mencegah berlanjutnya pelanggaran hak cipta, khususnya mencegah masuknya barang yang diduga melanggar hak cipta atau hak terkait ke dalam jalur perdagangan, termasuk tindakan importasi.

2. Menyimpan bukti yang berkaitan dengan pelanggaran hak cipta atau hak terkait tersebut guna menghidari terjadinya penghilangan barang bukti.

3. Meminta kepada pihak yang merasa dirugikan, untuk memberikan bukti yang menyatakan bahwa pihak tersebut memang berhak atas hak cipta atau hak terkait dan hak pemohon tersebut memang sedang dilanggar.

Proses keperdataan ini tentunya berlaku juga bagi pelanggar hak cipta atas VCD/ DVD bajakan. Akan tetapi, sangat jarang pihak pemegang hak cipta mengambil upaya hukum keperdataan ini. Ada beberapa alasan pihak pemegang hak cipta jarang melakukan upaya ini, di antaranya: Pertama, proses keperdataan biasanya membutuhkan biaya, waktu dan tenaga yang tidak sedikit; Kedua, proses keperdataan biasanya menuntut pemegang hak cipta untuk pro aktif di dalam menyelesaikan

${ }^{19}$ Merupakan hasil elaborasi dari ketentuan yang mengatur dan penjelasan tentang penetapan sementara yang terdapat di dalam ketentuan UU Hak Cipta. 
masalah. Hal ini tentu di anggap sebagai hal yang tidak produktif; Ketiga, sedikitnya atau minimnya pengetahuan pemegang hak cipta terhadap hukum hak cipta dan tidak terkecuali dalam konteks penyelesaian sengketa.

Atas dasar itu, maka tidak sedikit pihak-pihak yang merasa dirugikan dalam pelanggaran atas musik dan lagu dalam bentuk VCD/DVD bajakan akhirnya menempuh upaya hukum pidana. Sebagaimana diketahui, hukum hak cipta telah menentukan bahwa delik yang ditetapkan adalah delik biasa. Konsekuensi delik seperti ini adalah memposisikan pihak kepolisian harus proaktif dalam menyelesaikan pelanggaran hak cipta, dengan tidak harus menunggu adanya pelaporan dari pencipta/pemegang hak cipta.

Proses pidana ini diawali dengan tindakan penyidikan oleh pihak kepolisian. Setelah proses dikepolisian selesaikan, maka dilanjutkan ke pihak kejaksaan untuk dilakukan penuntutan. Apabila tuntutan telah dibuat, proses selanjutya adalah pemeriksaan di Pengadilan Negeri oleh pihak hakim. Hakim berperan tidak hanya memeriksa perkara tetapi hingga memutuskan perkara tersebut.

Di dalam hukum hak cipta telah dirumuskan beberapa tindakan/perbuatan yang dapat dikategorikan pelanggaran hak cipta. Hal ini dapat dilihat pada Pasal 72 ayat (1), (2), (3), (4), (5), (6), (7), (8), (9) UU Hak Cipta. Intinya beberapa perbuatan yang dapat dikategorikan sebagai tindak pidana adalah:

1. Perbuatan sengaja dan tanpa hak melakukan perbuatan berupa perbanyakan dan pengumuman ciptaan atau pelanggaran atas hak moral pencipta.

2. Perbuatan sengaja menyiarkan, memamerkan, mengedarkan atau menjual kepada pihak umum suatu ciptaan atau barang hasil pelanggaran hak cipta atau hak terkait.

3. Perbuatan sengaja dan tanpa hak memperbanyak penggunaan untuk kepentingan komersial suatu program komputer.

4. Perbuatan dengan sengaja melanggar dengan cara mengumumkan setiap ciptaan yang bertentangan dengan kebijaksanaan pemerintah di bidang agama, pertahanan dan keamanan negara, kesusilaan serta ketertiban umum.

5. Perbuatan sengaja melanggar Pasal 19, Pasal 20 atau Pasal 49 ayat (3).

6. Perbuatan sengaja dan tanpa hak melanggar Pasal 24 atau Pasal 55.

7. Perbuatan sengaja dan tanpa hak melanggar Pasal 25.

8. Perbuatan sengaja dan tanpa hak melanggar Pasal 27.

9. Perbuatan sengaja melanggar Pasal 28. 
Mencermati kategorisasi dari perbuatan pidana tersebut, maka bentuk memperjualbelikan musik dan lagu dalam bentuk VCD/DVD bajakan sesungguhnya sejalan dengan rumusan perbuatan yang pertama dan kedua.

Untuk permasalahan pelanggaran hak cipta dalam konteks pidananya dapat dikemukakan beberapa permasalahan juga yaitu; pertama, tindak pidana hak cipta apabila harus ditegakkan dalam pelanggaran hak cipta bagi pelanggar dipandang sebagai sebagai ultimum remedium, meskipun undang-undang sendiri tidak menyatakan demikian, sehingga hal ini berdampak pada penegakan hukum hak cipta; kedua, adanya pemahaman yang terbatas dari aparat penegak hukum tatkala akan menerapkan tindak pidana hak cipta kepada para pelanggar hak cipta. Konsekuensi lebih jauh tindak pidana hak cipta terkadang tidak efektif. adanya pemahaman yang terbatas dari aparat penegak hukum tatkala akan menerapkan tindak pidana hak cipta kepada para pelanggar hak cipta. Konsekuensi lebih jauh tindak pidana hak cipta terkadang tidak efektif. ${ }^{20}$

Setelah memahami pelanggaran hak cipta dan upaya hukum yang dapat dilakukan oleh pencipta/pemegang hak cipta serta permasalahannya, tentunya dapat diketahui bahwa pelanggaran hak cipta terjadi sesungguhnya bukan karena adanya beberapa permasalahan terkait dengan pelanggaran atas ketentuan hukum hak cipta saja. Tetapi ada permasalahan lainnya yang timbul dari pelanggaran hak cipta musik dan lagu dalam bentuk VCD/DVD bajakan. Hal-hal tersebut meliputi juga pada persoalan sosial ekonomi masyarakat.

Sebagaimana diketahui, bagi masyarakat Indonesia maraknya pelanggaran hak cipta tidak semata-mata dikarenakan tidak mengetahui pemberlakuan atas hukum hak cipta, tetapi dalih yang selama ini berkembang bahwa tindakan pelanggaran itu dilakukan mengingat tingkat sosial ekonomi masyarakat Indonesia yang masih rendah. Alhasil, dengan rendahnya tingkat ekonomi ini menjadikan masyarakat berani melakukan pelanggaran hukum hak cipta. Bagi mereka, prinsipnya bukan bagaimana hukum hak cipta dapat ditegakkan, tetapi yang lebih diutamakan adalah bagaimana kebutuhan ekonomi mereka dapat dipenuhi.

${ }^{20}$ Harian Radar Jogja, 27 September 2007. 


\section{Langkah - Langkah Hukum yang telah Ditempuh Pemerintah untuk Mengurangi Pelanggaran Hukum Hak Cipta atas Musik dan Lagu yang Dituangkan dalam Bentuk VCD/DVD.}

Dengan ditemukannya permasalahan-permasalahan dalam pelanggaran hak cipta atas musik dan lagu dalam bentuk VCD/DVD dibutuhkan berbagai langkah hukum. Langkah hukum ini adalah suatu tindakan yang diambil guna mengurangi pelanggaran hak cipta oleh pedagang VCD/DVD musik dan lagu bajakan. Tindakan tersebut dapat dilakukan oleh aparat pemerintah atau penegak hukum.

Dari penelitian yang telah dilaksanakan sebenarnya baik pemerintah maupun aparat penegak hukum telah mengambil langkah-langkah hukum terhadap pelanggaran hak cipta atas musik dan lagu dalam bentuk VCD/DVD bajakan.

Langkah-langkah hukum yang biasanya dilakukan oleh pemerintah, misalnya melakukan kegiatan sosialisasi tentang hak cipta dan melakukan kerjasama dengan instansi pemerintah pusat seperti Direktorat Jenderal HKI.

Dalam hal sosialisasi tentang hak cipta terkadang dilakukan oleh Setda Biro Hukum atau Kantor Wilayah Hukum dan HAM. Sosialisasi ini biasanya menghadirkan pakar-pakar dalam bidang hak cipta.

Sosialisasi atas hak cipta terkadang dilakukan juga oleh masyarakat. Hal ini sekaligus merupakan bentuk kepedulian masyarakat akan pentingnya melindungi dan menghargai hak cipta orang lain.

Salah satu persoalan di dalam memberikan sosialisasi ini memang pola sosialisasi belum dilakukan secara sistemik dan terkoordinasi. Bukti belum sistemiknya sosialisasi ini di mana belum ada target-target khusus dari pemerintah pada segmen masyarakat tertentu dalam bersosialisasi, sehingga dalam jangka waktu tertentu terbentuk kesadaran masyarakat atas hak cipta ini.

Selanjutnya, masalah lainnya dari langkah hukum yang diambil ini berupa belum terkoordinasikannya antar lembaga pemerintah dan antar lembaga pemerintah dengan lembaga swasta. Alhasil kecenderungan terjadinya duplikasi materi sosialisasi tidak dapat dihindarkan.

Langkah yang ditempuh oleh Aparat Penegak hukum dilakukan berupa penegakan hukum hak cipta. Penegakan hukum yang dilakukan dengan mengambil tindakan hukum refresif. Tindakan hukum refresif ini biasanya dilakukan dengan sistem terjadual. Istilah yang dikenal adalah tindakan razia. 
Penegakan hukum hak cipta oleh pihak kepolisian sebenarnya memposisikan polisi harus proaktif. Hal ini sejalan dengan delik pidana yang dianut yakni delik biasa. Delik biasa ini artinya polisi diberikan wewenang untuk mengambil tindakan hukum setiap saat jika ditemukan adanya pelanggaran hak cipta, tanpa harus menunggu adanya pengaduan dari pihak yang dirugikan.

Secara teoritik penerapan delik biasa dalam ketentuan hukum hak cipta dikarenakan adanya beberapa pertimbangan:

1. kerugian ditimbulkan dari adanya pelanggaran hak cipta tidak hanya diderita oleh pemegang hak cipta. Negara juga ikut dirugikan akibat tidak memperoleh pajak penghasilan atas keuntungan yang diperoleh dari pembajakan tersebut.

2. Adanya pelanggaran hak cipta yang tidak ditangani dengan serius pada akhirnya dapat menambah tatanana sosial, hukum dan ekonomi.

3. Pelanggaran hak cipta sebagai hak milik perorangan, lebih tepat diklasifikasikan sebagai delik biasa seperti halnya terhadap pencurian, perampasan, penipuan.

Dari hasil tindakan hukum refresif ini diperoleh hasil-hasil berupa tindakan penyitaan atas produk-produk VCD/DVD bajakan dengan jumlah 500 ribu keping.

Dalam hal penegakan hukum refresif ini nampaknya ada berbagai macam kendala yang ditemukan. Kendala tersebut, di antaranya; Pertama, dari segi ketentuan hukum hak cipta, masih disadari adanya perbedaan penafsiran terutama terkait dengan ketentuan Pasal 72 UU Hak Cipta. Untuk penerapan ketentuan Pasal 72 ini senantiasa harus menyertakan pelanggaran yang terdapat pada ayat (1). Padahal, pihak kepolisian dalam menerapkan ketentuan Pasal 72 ini tidak selalu menyertakan ketentuan Pasal 71 ayat (1).

Kedua, ketersediaan aparat penegak hukum yang terbatas dalam melakukan penanganan pelanggaran hak cipta. Di samping keterbatasan personil, juga aparat penegak hukum mengalami keterbatasan pemahaman atas hukum hak cipta. Maka, tidak jarang ketika aparat penegak hukum melakukan tindakan hukum senantiasa melibatkan ahli-ahli di bidang hak cipta.

Ketiga, budaya masyarakat yang belum kondusif bagi penegakan hukum hak cipta. Tindakan hukum yang dilakukan oleh penegak hukum sering dipahami sebagai suatu bentuk kesewenang-wenangan. Padahal, hal ini barangkali disebabkan budaya masyarakat terutama yang melakukan pelanggaran, di mana pelanggaran tersebut dianggap sebagai sesuatu yang biasa, bahkan cenderung mendapat "pembenaran." Sederhananya, budaya menghargai hak orang lain di masyarakat belum benar-benar terbangun. 
Keempat, penegakan hukum oleh aparat penegak hukum sering dibenturkan dengan tindakan-tindakan politis. Hal ini tentu berdampak buruk terhadap penegakan hukum hak cipta secara keseluruahan. Semisal, adanya tindakan demonstrasi oleh para pelanggar kepada pihak legislatif daerah. Tindakan demonstrasi itu sendiri mendapatkan tanggapan dari para wakil rakyat di daerah yang cenderung dipahaminya hanya dari segi politis.

Memahami sejumlah kendala dalam penegakan hukum hak cipta, maka diperlukan upaya-upaya pembenahan atas penegakan hukum hak cipta sendiri. Beberapa hal yang semetinya dilakukan guna menunjang efektifitas penegakan hukum ini dapat dilakukan melalui:

Pertama, perlunya ketentuan hukum dan perundang-undangan yang memadai serta adanya kepatuhan masyarakat untuk tidak melakukan pelanggaran.

Kedua, perlunya penegakan hukum yang konsisten. Penegakan hukum yang efektif, akan memberikan perlindungan kepada pemilik atau pemegang hak, yang selanjutnya akan dapat memberikan manfaat bagi peningkatan berbagai kegiatan dalam masyarakat umum, negara dan perekonomian nasional.

Ketiga, diperlukan kerjasama, koordinasi dan strategi yang terpadu antara aparat penegak hukum. Penegakan hukum oleh aparat pemerintah dilaksanakan oleh berbagai instansi yang terkait antara lain; Kepolisian, Kejaksaan, Hakim, Ditjen HKI, Deperindag, Pemda dan lain-lain.

Sejalan dengan itu Ramelan memberikan pendapatnya bahwa dalam melakukan penegakan hukum hak cipta diperlukan kebijakan dan strategi penegakan hukum. Untuk kebijakan penegakan hukum hak cipta menurutnya dapat dilakukan melalui hal-hal sebagai berikut:

Pertama, pendekatan komprehensif yaitu pendekatan yuridis dalam rangka mewujudkan cita ketertiban dan kepastian hukum, pendekatan filosofis dalam rangka menegakan cita keadilan, dan pendekatan sosiologis dalam rangka mewujudkan cita manfaat bagi masyarakat. Pendekatan tersebut dilaksanakan dengan mengindahkan norma-norma keagamaan serta menggali nilai-nilai kemanusiaan, hukum dan keadilan yang hidup dalam masyarakat.

Kedua, membangun kepercayaan masyarakat terhadap hukum dengan memberdayakan institusi penegakan hukum.

Ketiga, sumber daya manusia memiliki peran yang menentukan dalam mengemban dan mengembangkan misi aparat penegak hukum, di samping sarana 
dan prasarana. Untuk masud tersebut, kebijakan penegakan hukum hak cipa di arahkan untuk meningkatkan kualitas sumber daya manusia, sehingga memiliki kemampuan serta keterampilan yang meliputi: a). Pengembangan profesionalisme di bidang penguasaan pengetahuan teknis dan menajerial; b). Meningkatkan integritas kepribadiaan; c). Memupuk siakp/kader disiplin aparatur.

Keempat, membangun budaya masyarakat yang patuh dan taat hukum sebagai iklim yang kondusif dalam penegakan hukum.

Untuk strategi penegakan hukum hak cipta beberapa hal yang harus dilaksanakan adalah:

Pertama, penyidikan dan penuntutan tindak pidana hak cipta diarahkan untuk mengungkap sumber kejahatan yang melibatkan pelaku-pelaku produsen kejahatan hak cipta bukan sekedar pengedar atau pemakai. Stretegi ini dimaksudkan untuk membangun dan memulihkan kepercayaan masyarakat domestik maupun internasional bahwa pemerintah benar-benar serius memberikan perlindungan hak cipta.

Kedua, meningkatkan pelaksanaan penerapan dan penegakan hukum yang memberikan kepastian hukum dan keadilan kepada masyarakat pencari keadilan. Strategi ini dimaksudkan agar proses penegakan hukum berlangsung secara proposional dan profesional, sehingga aparat penegak hukum terhindar daro kesalahan dalam proses penyidikan, penuntutan, putusan dan ekekusi.

Ketiga, menerapkan prinsip-prinsip akutabilitas dan transparansi dalam penegakan hukum hak cipta. Strategi ini ditujukan sebagai bentuk pertanggung jawaban kepada publik. Untuk itu agar diupayakan publikasi penanganan perkara sejak dari penyidikan sampai dengan eksekusi secara terus menerus sehingga masyarakat mengetahui dan mengikuti perkembangan penyelesaian perkara tersebut secara benar. Dengan demikian diharapkan masyarakat dapat menentukan posisi partisipasinya dalam pemberantasan dan penegakan kejahatan hak cipta.

Keempat, mengembangkan sistem manajemen dan organisasi penegak hukum yang mantap sebagai pengayom masyarakat. Strategi ini dimaksudkan agar masyarakat dengan mudah dan jelas menyampaikan laporan atas kejahatan yang ditemukan kepada aparat penegak hukum.

Kelima, mengembangkan keterpaduan dalam proses penegakan hukum melalui penyelidikan/penyidikan gaubngan antara penyidik dan penuntut umum. Strategi ini dimaksudkan untuk mempercepat proses penanganan perkara, mencegah terjadinya bolak-balik perkara antara penuntut umum dengan penyidik. 


\section{Penutup}

Dengan berdasarkan pada hasil pembahasan pada bab sebelumnya, maka penelitian ini dapat menyimpulkan dua hal, yakni; Pertama, pelanggaran hak cipta terjadi disebabkan adanya permasalahan hukum hak cipta. Permasalahan tersebut mencakup pada permasalahan penyelesaian pelanggaran baik secara keperdataan maupun pidana. Di samping itu, permasalahan lainnya yang timbul dari pelanggaran hak cipta musik dan lagu yang dituangkan dalam bentuk VCD/DVD disebabkan persoalan sosial ekonomi masyarakat (baca: pelanggar). Kedua, untuk menyelesaikan permasalahan pelanggaran hak cipta musik dan lagu yang dituangkan dalam bentuk VCD/DVD ini biasanya ditempuh oleh pemerintah dengan melakukan dua langkah, yakni; sosialisasi hukum hak cipta dan melakukan penegakan hukum hak cipta. Sosialisasi ini dilaksanakan oleh beberapa lembaga pemerintahan seperti Setda Biro Hukum, Desperindag, Kanwil Hukum dan HAM dan instansi lainnya dengan menghadirkan nara sumber yang dianggap ahli di dalam hukum hak cipta. Penegakan hukum hak cipta merupakan langkah berikutnya. Penegakan hukum yang dilakukan dengan mengambil tindakan hukum represif.

\section{Daftar Pustaka}

Edy Damian, Hukum Hak Cipta UU No. 19 Tahun 2002, Bandung, Alumni, 2004.

Hendra Tanu Wijaya, Hak Cipta Musik atau Lagu, Jakarta, UI Press, 2003.

Insan Budi Maulana, Pelangi HKI dan Anti Monopoli, Yogyakarta, FH UII, 2000.

Muhammad Jumhana, Hak Kekayaan Intelektual Teori dan Prakteknya, Bandung, Citra Aditya Bakti, 1997.

Rachmadi Usman, Hukum Hak Atas Kekayaan Intlektual Perlindungan dan Dimensi Hukumnya di Indonesia, Bandung, PT. Alumni, 2003.

Tim Linsey dkk., Hak Kekayaan Intelektual Suatu Pengantar, Bandung, Alumni, 2005.

Data Diperoleh dari Ditjen Bea Cukai Tahun 2003.

Harian Radar Jogja Tanggal 27 September 2007.

Hasil wawancara dengan para pedagang VCD/DVD bajakan di Jalam Mataram hari Sabtu, 14 Juli 2007. 